\title{
ANALISIS TURN AROUND TIME (TAT) PADA PROSES POOLING KOMPONEN PESAWAT: STUDI KASUS KETERLAMBATAN PENGEMBALIAN KOMPONEN PESAWAT CRJ 1000 NEXTGEN DI PT. GAA
}

\author{
Novie Susanto*), Damar Azis \\ Program Studi Teknik Industri, Fakultas Teknik, Universitas Diponegoro, \\ Jl. Prof. Soedarto, SH, Kampus Undip Tembalang, Semarang, Indonesia 50275
}

\begin{abstract}
Abstrak
Penelitian ini membahas mengenai proses kontrol turn around time (TAT) pada proses pooling komponen pesawat regional. TAT adalah batasan waktu yang diberikan oleh vendor untuk melakukan pengembalian komponen pesawat yang dipinjam atau disewa. TAT yang diberikan oleh vendor selama 10 hari. Pada kenyataannya banyak sekali keterlambatan yang terjadi dalam pengembalian komponen, keterlambatan ini akan menimbulkan charge yang berdampak pada penambahan cost yang perlu dibayarkan ke vendor. Untuk itu dilakukan analisis penyebab terlewatinya TAT dengan studi kasus pesawat CRJ 1000 NextGen. Metode yang digunakan dalam analisis adalah diagram sebab akibat (cause and effect diagram) dan metode 5 why. Berdasarkan analisis dengan menggunakan diagram sebab akibat didapat penyebab masalah TAT pengembalian yang melewati batas ditemukan 4 penyebab utama yaitu: (1) kesalahan operator dalam menangani komponen, (2) penanganan komponen di bagian import-eksport, (3) kelengkapan berkas komponen dan jarak ke OSA dan (4) Alat bantu angkut masih terbatas. Saran yang dapat diberikan berdasarkan hasil penelitian adalah perbaikan manajemen pengecekan dan pemberkasan dalam sistem, menghindari penundaan pengembalian komponen ke vendor, menambah alat angkut dan penerapan alur proses komponen pooling optimal 10 atau 14 hari.
\end{abstract}

Kata kunci: turn around time (TAT); diagram sebab akibat; metode 5 why; keterlambatan komponen

\begin{abstract}
[Analysis of Turn Around Time (TAT) on the Pooling Process of Aircraft Components: A Case Study of Component Returning Delay in CRJ 1000 NextGen Aircraft in PT. GAA]. This study discusses the control process of turn around time (TAT) in the pooling process of regional aircraft components. TAT is the time limit given by the vendor to refund the aircraft components borrowed or rented. TAT provided by vendors is 10 days. In fact, there are a lot of delays in returning the items that cause a delay charge. This charge affects an additional cost that needs to be paid to the vendor. Therefore, analysis of TAT is conducted with a case study in 1000 CRJ NextGen aircraft. The method used in the analysis are the cause and effect diagram and 5 why method. Based on the analysis using causal diagram, it is obtained the four main causes of problems are: (1) The operator error in the handling of components, (2) the handling of components in the import-export, (3) the completeness of the file components and distance to OSA and (4) The tool carrier is still limited. Advice can be given based on the results of the study are improvement of checking and filling management system, avoiding delays the return of the components to the vendor, adding conveyance and application of optimal process flow pooling component within 10 or 14 days..
\end{abstract}

Keywords: turn around time (TAT); cause and effect diagram; 5 why method; component delay

\section{Pendahuluan}

PT GAA merupakan salah satu perusahaan MRO (Maintenance, Repair and Overhoul) pesawat terbang terbesar di Asia yang mempekerjakan 2.500 karyawan. PT GAA berdiri sejak tahun 2002 dan

\footnotetext{
${ }^{*}$ Penulis Korespondensi.

email: nophie_susanto@yahoo.com.sg
}

Jurnal Teknik Industri, Vol. XI, No. 1, Januari 2016 merupakan perusahaan pengadaan jasa perbaikan pesawat terbang di kawasan Asia Pasifik. Industri MRO yang berkembang akan memerlukan analisis lanjut untuk menentukan jumlah komponen yang bisa diperbaiki sebagai stok pengganti, mencapai service level yang ditentukan berdasarkan distribusi Poisson yaitu Turn Around Time (TAT) (Kaul dan Stefka, 2008). Hal ini sesuai dengan pendapat Kilpi dan Vepsalainen (2004) yang menyatakan bahwa ada 4 
faktor yang mempengaruhi biaya ketersediaan komponen: (1) keandalannya, (2) TAT proses reparasi, (3) service level yng diperlukan dan (4) jumlah unit terproteksi.

Proses perawatan yang diterapkan di perusahaan ini berupa proses repair, pooling maupun exchange dengan provider lain. Pada proses repair, komponen yang rusak akan diperbaiki sendiri sedangkan pada proses pooling, komponen yang rusak akan dikirim kepada provider/vendor untuk kemudian ditukar dengan komponen yang siap pakai. Setiap komponen pada pesawat memiliki dampak yang berbeda ketika rusak sehingga terdapat 3 jenis kriteria yaitu, no go, go if dan $g o$.

Pelaksanaan perencanaan komponen melibatkan beberapa divisi lainnya, seperti divisi produksi, material dan sistem SAP perusahaan. SAP perusahan merupakan aplikasi ERP (Enterprise Resource Planning) yang mengintegrasikan data pada setiap tahapan proses bisnis. Permasalahan yang ada dalam divisi perencanaan komponen adalah data yang didapatkan dari SAP perusahaan seringkali tidak sesuai dengan kondisi komponen pesawat yang sebenarnya sehingga komponen time control harus selalu dilakukan pengecekan setiap hari untuk dilakukan perencanaan perawatan.

Penelitian ini membahas mengenai proses kontrol turn around time (TAT) pada proses pooling komponen pesawat regional. Secara umum, TAT adalah waktu yang diperlukan untuk memenuhi suatu permintaan. Dalam bidang komputasi, TAT ditujukan untuk mendefinisikan total waktu yang diperlukan mulai dari suatu program dujalankan untuk suatu tugas sampai dengan pengeluaran ouput secara komplit kepada pemakai (The Free Dictionary, 2015). Dalam penelitian ini, TAT secara spesifik digunakan untuk merepresentasikan batasan waktu yang diberikan oleh vendor untuk melakukan pengembalian komponen pesawat yang dipinjam atau disewa. TAT yang diberikan oleh vendor untuk pesawat jenis ini selama 10 hari. Pada kenyataannya banyak sekali keterlambatan yang terjadi dalam pengembalian komponen. TAT merupakan bagian dari repair cycle yang termasuk dalam manajemen off-wing (Rajarajan, 2013; IATA, 2014; IATA, 2015). Dengan peranan TAT dalam manajemen biaya perawatan, keterlambatan pengembalian komponen akan menimbulkan charge yang berdampak pada penambahan cost yang perlu dibayarkan ke vendor.

Perencanaan akan dilakukan pada komponenkomponen yang akan dilakukan penggantian dan perawatan pada pesawat CRJ. Proses ini dilakukan pada salah satu pesawat CRJ 1000 NextGen. Pesawat CRJ 1000 NextGen dipilih dikarenakan ini adalah pesawat yang baru digunakan dan sedikit berbeda dengan pesawat lain yang digunakan seperti Airbus dan Boeing. Analisis dilakukan terhadap data pengembalian komponen ke vendor dengan menggunakan metode 5 why (Ohno, 1988) dan diagram sebab akibat (cause and effect diagram)
(Ishikawa, 1968). Data komponen yang diteliti diambil pada periode September 2014 sampai Januari 2015. Berdasarkan latar belakang tersebut maka permasalahan dalam penelitian ini adalah ketersediaan komponen untuk proses repairing dan tidak tepatnya waktu pengembalian komponen ke vendor (TAT). Tujuan penelitian ini adalah untuk mengetahui dan menganalisa penyebab keterlambatan TAT dan melakukan upaya perbaikan untuk mengurangi keterlambatan TAT

\section{Metode Penelitian}

Penelitian dimulai dengan dilakukannya studi pendahuluan yang dilakukan baik secara studi lapangan maupun studi pustaka. Studi lapangan dilakukan dengan cara in-depth interview kepada PT GAA mengenai pooling komponen yang dilakukan dalam proses repair pada pesawat CRJ. Selain itu studi lapangan juga dilakukan dengan tinjauan langsung ke dalam pesawat yang akan dilakukan perawatan dengan melakukan kontrol terhadap komponen-komponen pesawat.

Langkah selanjutnya adalah dengan melakukan pengumpulan data yang dibutuhkan untuk bahan penelitian. Data ini diperoleh berdasarkan data SAP (system application product) periode September 2014 - Januari 2015 pada proses component pooling pesawat regional CRJ 1000 NextGen. Setelah data terkumpul, kemudian dilakukanlah pengolahan data dengan kontrol manual terhadap setiap komponen yang dipesan ke vendor untuk kemudian diolah dan menghitung Service Level setiap bulannya. Selanjutnya dilakukan analisa penyebab keterlambatan TAT.dengan metode 5 Why dan diagram sebab akibat. Hasil pengolahan data tersebut kemudian dianalisis untuk merumuskan rekomendasi yang diperlukan sebagai pemecahan masalah.

\section{Hasil Dan Pembahasan}

Berdasarkan hasil penelitian didapatkan rekap data jumlah komponen pooling yang terlambat dikembalikan ke vendor seperti terlihat pada Gambar 1. Grafik ini menunjukkan jumlah pengembalian komponen yang terlambat dan tepat waktu tiap bulannya. Berdasarkan data tersebut, analisis service level setiap bulannya dapat dilakukan dengan cara membagi jumlah pengembalian komponen tepat waktu dengan jumlah pengembalian komponen total. Hasilnya dikonversi dalam bentuk persentase dengan faktor pengali $100 \%$. Konsep service level (SL) digunakan untuk mengindikasikan probabilitas sebuah spare unit tersedia saat ada permintaan (Gayer, 2010). Bila terdapat level s pada inventori, Muckstadt (2005) mendefinisikan service level sebagai fraksi permintaan yang dapat dipenuhi secepatnya melalui spare unit yang tersedia di gudang. Bila s meningkat, maka service level juga meningkat. 


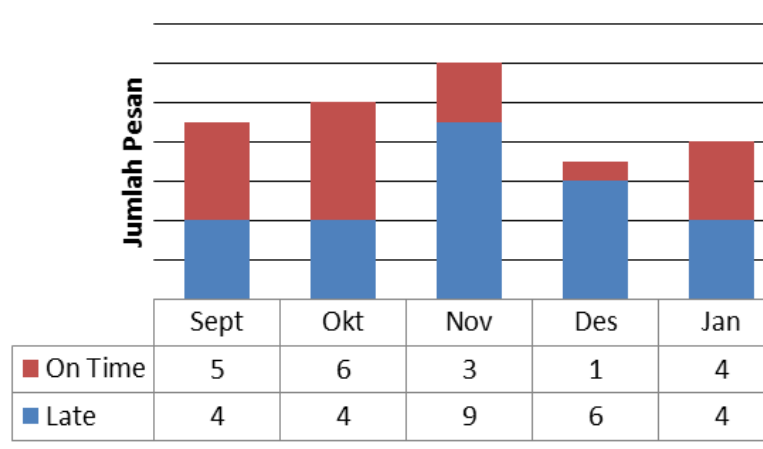

Gambar 1. Data Pengembalian Komponen Pooling

Grafik service level dapat dilihat pada Gambar 2. Gambar 2 menunjukkan bahwa tidak ada service level yang mencapai target $100 \%$, pencapaian terbesar ada pada bulan Oktober dengan 60\% dan pencapaian terkecil pada bulan Desember dengan presentase 14.29\%. Hal ini terjadi karena banyaknya pengembalian komponen terlambat sehingga mempengaruhi service level. Service level ini sangat dipengaruhi tingkat pengembalian komponen yang tepat waktu.

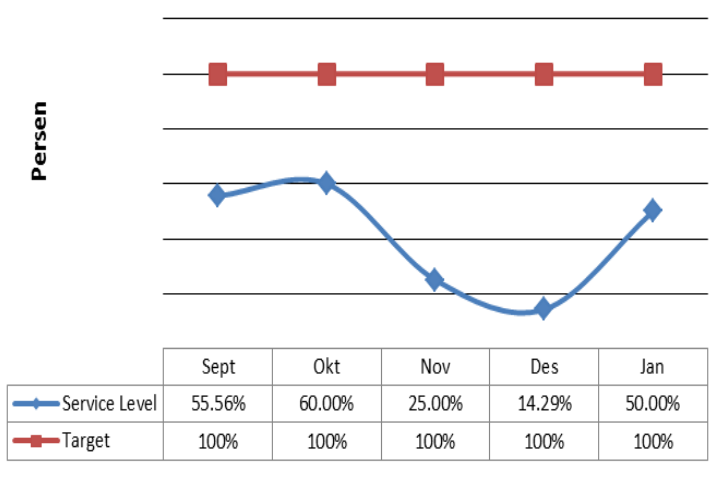

Gambar 2. Service Level
Langkah selanjutnya adalah melakukan perbandingan TAT vendor dengan TAT aktual seperti terlihat pada Gambar 3. Gambar 3 menunjukkan bahwa secara aktual TAT yang diberikan oleh vendor hanya terpenuhi di bulan Oktober. Hal itu terjadi karena pengembalian komponen oleh OSA lebih tepat waktu dibanding bulan lainnya

Dari data penelitian yang ada dapat dilakukan analisis komponen pooling dengan metode 5 Why. Analisis dengan menggunakan metode 5 Why merupakan analisis mencari akar permasalahan dengan menanyakan kepada narasumber di bidang terkait dengan pertanyaaan "mengapa" sebanyak 5 kali sampai ditemukan akar permasalahan yang ada. Analisis 5 Why dilakukan terhadap permasalahan keterlambatan pengembalian komponen pooling pada jenis pesawat CRJ 1000 NextGen. Tabel 1 menggambarkan analisis dengan metode 5 Why.

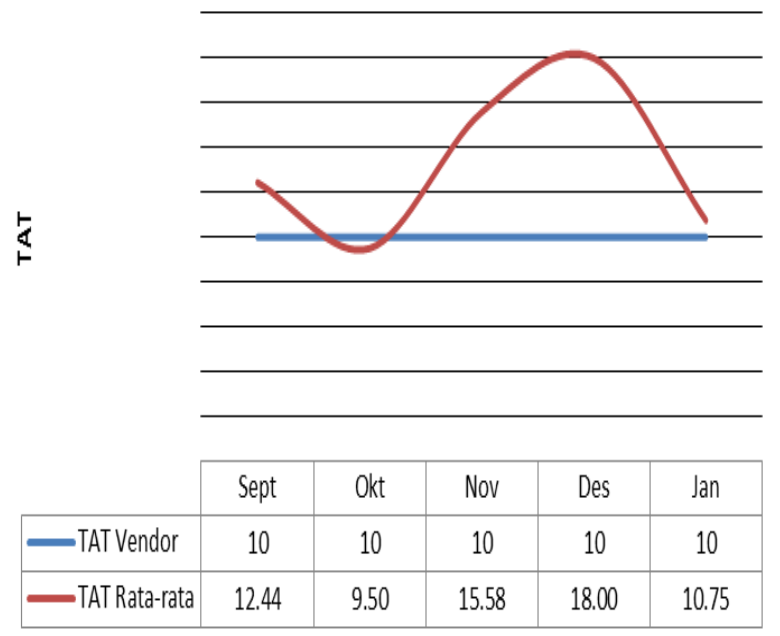

Gambar 3. Perbandingan TAT vendor dan TAT aktual

Tabel 1. Analisis metode 5 Why

\begin{tabular}{|c|c|c|c|c|}
\hline Why 1 & Why 2 & Why 3 & Why 4 & Why 5 \\
\hline $\begin{array}{l}\text { Operator/mekanik } \\
\text { salah menempatkan } \\
\text { komponen }\end{array}$ & $\begin{array}{l}\text { Operator/mekanik } \\
\text { salah melakukan } \\
\text { identifikasi } \\
\text { komponen }\end{array}$ & $\begin{array}{l}\text { Operator/mekanik } \\
\text { salah membaca part } \\
\text { number komponen }\end{array}$ & $\begin{array}{l}\text { Part number tidak } \\
\text { tertera dengan } \\
\text { jelas }\end{array}$ & $\begin{array}{l}\text { Berkas berkas } \\
\text { komponen } \\
\text { tidak lengkap }\end{array}$ \\
\hline $\begin{array}{l}\text { Komponen rusak } \\
\text { belum diterima oleh } \\
\text { GAA }\end{array}$ & $\begin{array}{l}\text { Pihak Outstation } \\
\text { terlambat mengirim } \\
\text { komponen pesawat } \\
\text { yang rusak }\end{array}$ & $\begin{array}{l}\text { Pengangkutan } \\
\text { komponen } \\
\text { menunggu pesawat } \\
\text { lain yang menuju } \\
\text { Cengkareng }\end{array}$ & $\begin{array}{l}\text { Untuk mengurangi } \\
\text { biaya angkut } \\
\text { komponen dengan } \\
\text { menggunakan } \\
\text { carrier } \\
\end{array}$ & $\begin{array}{l}\text { Jarak } \\
\text { Outstation } \\
\text { yang jauh dari } \\
\text { GAA pusat di } \\
\text { Cengkareng } \\
\end{array}$ \\
\hline $\begin{array}{l}\text { Komponen belum } \\
\text { sampai ke vendor }\end{array}$ & $\begin{array}{lr}\text { Dokumen } & \text { Ekspor } \\
\text { barang } & \text { belum } \\
\text { disetujui } & \\
\end{array}$ & $\begin{array}{l}\text { Komponen } \\
\text { dikumpulkan dulu } \\
\text { sebelum di ekspor }\end{array}$ & $\begin{array}{lr}\text { Untuk } & \text { memenuhi } \\
\text { kuota } & \text { angkut } \\
\text { komponen } & \\
\end{array}$ & $\begin{array}{l}\text { Meminimasi } \\
\text { biaya angkut }\end{array}$ \\
\hline $\begin{array}{l}\text { Komponen } \\
\text { diberikan } \\
\text { divisi ekspor-impor }\end{array}$ & $\begin{array}{l}\text { Sering terjadi } \\
\text { penumpukan pada } \\
\text { hari jumat }\end{array}$ & $\begin{array}{l}\text { Komponen banyak } \\
\text { yang tertumpuk di } \\
\text { gudang }\end{array}$ & $\begin{array}{l}\text { Penundaan } \\
\text { packaging } \\
\text { komponen }\end{array}$ & $\begin{array}{l}\text { Regulasi waktu } \\
\text { kerja hanya } 5 \\
\text { hari pada divisi } \\
\text { ekspor-impor }\end{array}$ \\
\hline
\end{tabular}


Analisis selanjutnya adalah mencari penyebab keterlambatan proses pengembalian komponen dengan cause and effect diagram seperti terlihat pada Gambar 4.

\section{Man}

- Operator salah mengidentifikasi komponen Penyebab masalah ini karena operator salah mengartikan serial number atau part number komponen yang datang. Hal ini dapat menyebabkan salah pemasangan pada pesawat.

- Operator salah menempatkan komponen di gudang

Masalah ini dapat terjadi karena operator yang tidak memperhatikan lokasi penyimpanan barang. Masalah ini membuat barang sulit untuk dicari karena diletakkan tidak pada tempatnya

- Operator lupa untuk menyertakan alamat tujuan yang jelas

Masalah ini biasa terjadi saat komponen yang hendak dikirim ke vendor. Tanpa alamat yang jelas pihak yang mengirim komponen akan kesulitan mencari alamat vendor.

\section{Method}

- Regulasi waktu kerja hanya 5 hari (sabtu-minggu libur)
Masalah ini terjadi pada divisi import-eksport, pada divisi tersebut waktu kerja hanya 5 hari saja sedangkan proses perawatan pesawat dilakukan 7 hari dalam seminggu. Seringkali terjadi penumpukan komponen yang akan dikirim pada hari Jumat, karena divisi import-eksport hanya melayani pengiriman barang dari Senin-Jumat saja dan komponen yang menumpuk akan dikirim pada hari Senin. Hal ini membuat terjadi keterlambatan dalam mengembalikan komponen ke vendor karena TAT melewati batas dari perjanjian.

- $\quad$ Persetujuan eksport barang tidak disetujui Masalah ini terjadi karena dokumen dari komponen yang hendak dikirim tidak lengkap sehingga komponen tidak dapat dikirim dan harus menunngu kelengkapan dokumen untuk diproses lagi.

- Material dikumpulkan dulu sebelum dieksport Metode pengiriman ini merupakan kebijakan untuk mengurangi biaya kirim komponen karena komponen baru akan dikirim ketika sudah mengisi kuota yang tersedia sehingga tidak perlu untuk mengirim secara berulang ulang. Kebijakan ini membuat masalah baru yaitu terlambatnya komponen yang dikirim kepada vendor karena komponen harus menunggu sebelum dikirim yang berakibat pada TAT yang melewati batas.

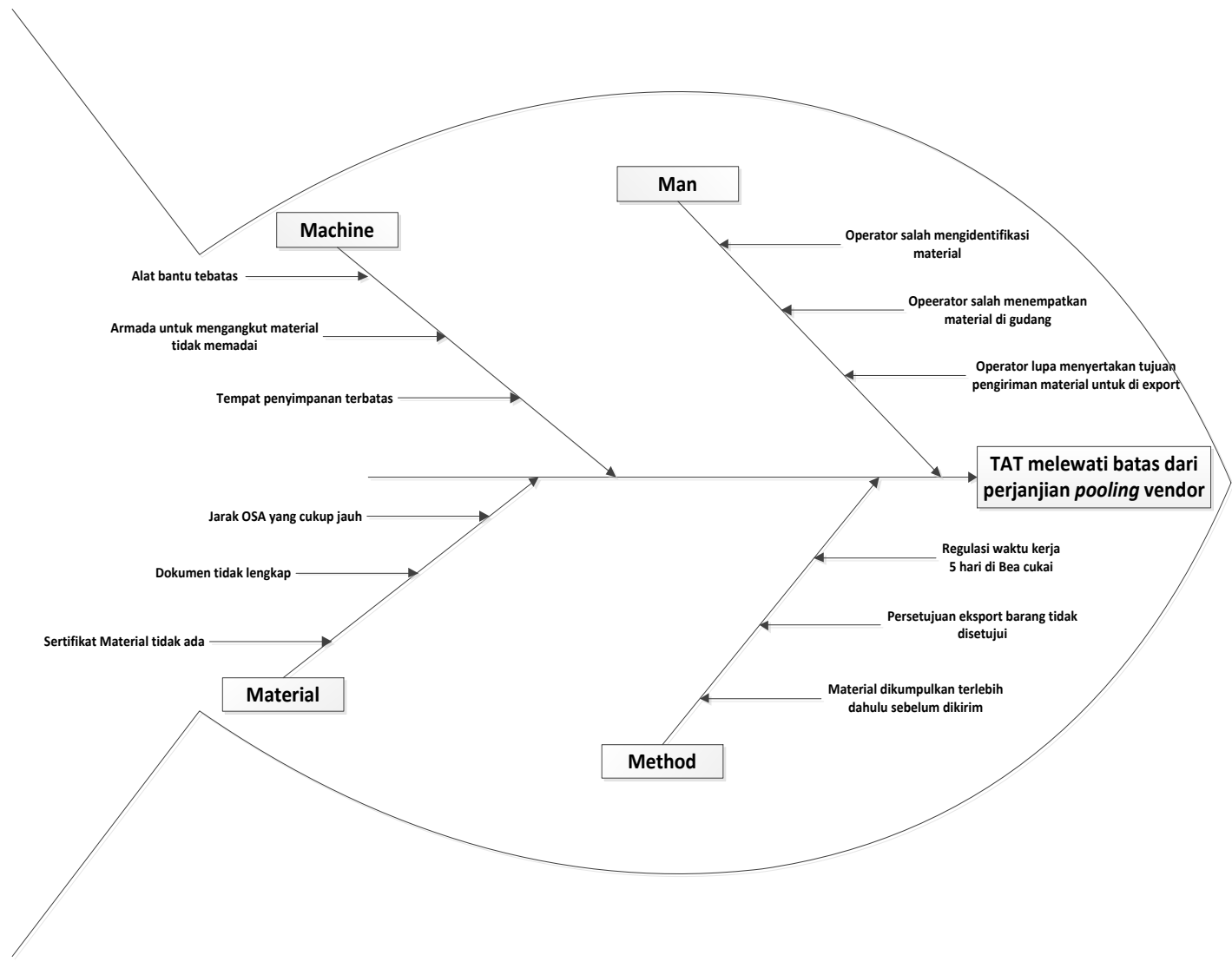

Gambar 4. Diagram sebab akibat TAT melewati batas perjanjian pooling vendor 


\section{Material}

- Jarak OSA yang cukup jauh

Faktor ini menjadi penyebab utama dalam masalah TAT yang melewati batas. Jarak OSA yang jauh menyebabkan perlunya pengiriman internal oleh PT. GAA, karena komponen yang dikirim oleh vendor ditujukan ke kantor pusat PT. GAA. Pengiriman internal dari kantor pusat ke OSA akan membutuhkan waktu tambahan. Hal itu membuat TAT menjadi lama. OSA atau outstation merupakan tempat maintenance yang berada di luar Cengkareng, sedangkan OSA untuk pesawat jenis CRJ ada di Ujung Pandang dan Medan.

- Dokumen tidak lengkap

Dokumen yang tidak lengkap akan menimbulkan masalah pada saat custom clearance atau pemeriksaan berkas. Jika berkas tidak lengkap maka pihak custom clearance akan menahan komponen selama 3 hari untuk melengkapi dokumen yang belum lengkap. Jika dalam 3 hari dokumen belum dilengkapi kekurangannya maka komponen tersebut akan dikembalikan lagi ke vendor.

- Sertifikat komponen tidak ada

Sertifikat komponen adalah salah satu berkas yang penting akan diperiksa oleh pihak quality. Berkas itu berisi mengenai standar komponen yang dikirim, selain itu berisi tentang status komponen apakah baru dibuat atau baru diperbaiki. Jika sertifikat ini tidak ada maka dari pihak quality menunggu untuk dilengkapi berkasnya, jika tidak segera dilengkapai maka akan dikembalikan ke vendor tempat komponen tersebut berasal.

\section{Machine}

- Alat bantu terbatas

Alat bantu berupa mobil pengangkut komponen dari apron ke gudang dan sebaliknya belum maksimal. Hal ini seringkali menyebabkan komponen harus mengantri untuk diambil sebelum bisa dipasangkan ke pesawat atau disimpan ke gudang.

- Armada pengangkut tidak memadai

Dalam pengiriman komponen, seringkali PT. GAA menumpang pada pesawat yang dirawat untuk meminimalkan ongkos pengiriman. Karena pengiriman bergantung pada pesawat tersebut, maka jika terjadi gangguan dalam penerbangan maka pengiriman pun akan mengalami gangguan juga. Misalnya jika pesawat tersebut mengalami kerusakan maka penerbangan pun dibatalkan hal itu juga berpengaruh pada pengiriman. Pihak PT. GAA harus mencari alternatif pengganti yaitu dengan mencari forwarder. Dengan memakai jasa forwarder akan menambah biaya dan waktu TAT pengembalian.

- Tempat penyimpanan terbatas

Salah satu hal yang penting dalam melakukan pooling komponen adalah tersedianya tempat penyimpanan atau gudang. Saat ini tempat

Jurnal Teknik Industri, Vol. XI, No. 1, Januari 2016 penyimpanan yang terbatas menjadi kendala dalam menyimpan komponen yang ingin dipakai dalam proses maintenance maupaun sebagai floating spare. Dengan tempat penyimpanan yang terbatas maka komponen yang baru datang harus menunggu komponen lama di gudang untuk dikeluarkan terelebih dahulu sebelum dapat disimpan.

Rekomendasi yang dapat diberikan berdasarkan hasil penelitian adalah:

1. Operator sebaiknya lebih teliti lagi dalam menangani komponen dan melakukan pengecekan di sistem apakah komponen yang datang sudah sesuai dengan yang tercatat di sistem. Sebaiknya dilakukan pelatihan kepada operator yang menangani komponen tersebut.

2. Dalam pengembalian komponen unserviceable sebaiknya tidak dipadatkan pada hari Jumat karena jika terlalu banyak dan tidak dapat dikirim semuanya maka akan dikirim pada hari selanjutnya yaitu hari Senin. Sementara jika dikirim hari Senin akan terjadi keterlambatan dalam pengembalian ke vendor

3. Untuk mengatasi komponen yang berkasnya tidak lengkap pihak purchaser sebaiknya langsung meminta pooling provider untuk segera melengkapi berkasnya agar komponen dapat langsung dipakai atau disimpan. Antara purchaser dan pooling provider atau vendor harus berkoordinasi dengan baik agar tidak terjadi miskomunikasi

4. Untuk permasalahan ini PT GAA dapat menambahkan alat angkut guna membawa komponen dari apron ke gudang ataupun sebaliknya. Sedangkan untuk armada angkut untuk mengambil atau ke mengembalikan ke vendor dapat mencari forwarder untuk menjadi alternatif jika terjadi kendala pada pesawat yang ditumpangi.

Selain rekomendasi diatas, dibawah ini adalah rekomendasi alur proses komponen pooling untuk memaksimalkan TAT yang sudah disetujui oleh kedua belah pihak seperti terlihat pada Gambar 6. Gambar 6 menunjukkan alur proses komponen pooling untuk memaksimalkan TAT yang disetujui bersama yaitu 10 hari. Alur tersebut mempercepat proses kerja pada receiving menjadi 1 hari dan memuntut OSA untuk mengembalikan komponen maksimal 1 hari setelah diterima.

Selain itu rekomendasi alur proses komponen pooling untuk memaksimalkan TAT optimal berdasarkan data rata-rata TAT selama periode September 2014 - Januari 2015 adalah 14 hari seperti terlihat pada Gambar 7. Gambar 7 menunjukkan alur proses komponen pooling untuk memaksimalkan TAT yang yaitu 14 hari. Alur tersebut mempercepat proses kerja pada receiving menjadi 1 hari, memberi kesempatan OSA untuk mengembalikan komponen maksimal 3 hari setelah diterima, menambah waktu pengambilan komponen menuju ke cardex menjadi 2 hari karena sering terjadi penumpukan komponen. 


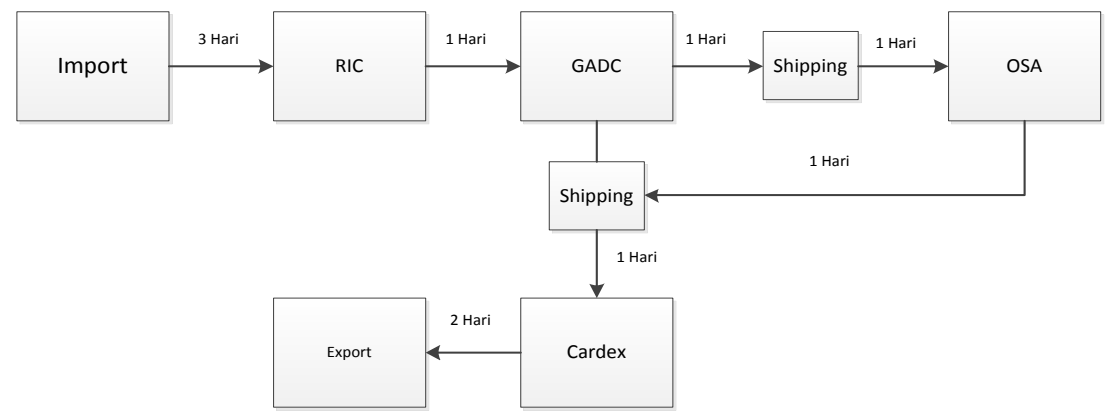

Gambar 6 Alur proses komponen pooling TAT 10 hari

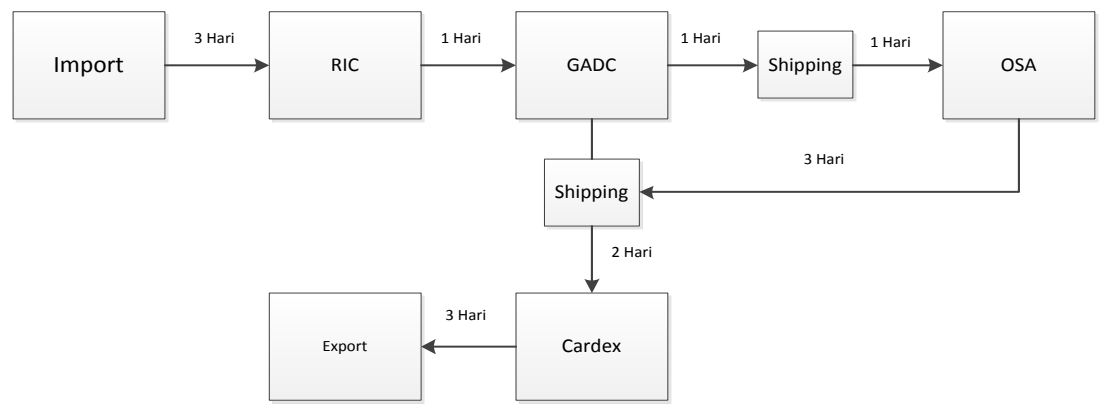

Gambar 7. Alur proses komponen pooling TAT 14 hari

\section{Kesimpulan}

Kesimpulan penelitian ini adalah bahwa ditemukan masalah keterlambatan pengembalian komponen ke vendor selama periode September 2014 - Januari 2015. Selama periode tersebut tingkat pengembalian komponen on time sangat kecil. Pencapaian terbesar ada pada bulan September 2014 dengan tingkat pengembalian on time sebanyak 5 komponen 9 komponen yang dipesan dan pencapaian terkecil pada bulan November dengan tingkat pengembalian on time sebanyak 1 dari 12 komponen yang dipesan.

Tingkat service level jauh dari target yang ingin dicapai yaitu selalu $100 \%$. Pada bulan September 2014, service level sebesar 55,56\%, pada bulan Oktober 2014 service level sebesar 60\%, pada bulan November 2014 service level sebesar 25\%, pada bulan Desember 2014 service level sebesar 14,29\%, dan pada bulan Januari 2015 service level sebesar 50\%.

Berdasarkan analisis dengan menggunakan metode 5 whys dan diagram sebab akibat didapat penyebab masalah TAT pengembalian yang melewati batas ditemukan 4 penyebab utama yaitu: (1) kesalahan operator dalam menangani komponen, (2) penanganan komponen di bagian import-eksport, (3) kelengkapan berkas komponen dan jarak ke OSA dan (4) alat bantu angkut masih terbatas.

Saran yang dapat diberikan berdasarkan hasil penelitian adalah perbaikan manajemen pengecekan dan pemberkasan dalam sistem, menghindari penundaan pengembalian komponen ke vendor, menambah alat angkut dan penerapan alur proses komponen pooling optimal 10 atau 14 hari.

\section{Daftar Pustaka}

Gayer, C.F. (2010). Assessment of Poisson Model for Airliners' Repairable Spare Parts Demand Forecasting. Journal of the Brazilian Air Transportation Research Society. 6 (1). 2010.

International Air Transport Association (IATA). (2014). Component Maintenance - Best Practices: An Airline Perspective. IATA MCC. Athens. September 2014.

International Air Transport Association (IATA). (2015). Best Practice for Component Maintenance Cost Management. International Air Transport Association. Montral-Geneva.

Ishikawa, K (1968). Guide to Quality Control. Tokyo: JUSE.

Kaul, F.T dan Stefka, T. (2008). Initial Provisioning Training - Part 3: The Mathematical Model. Airbus Provisioning Services.

Kilpi, J. dan Vepsalainen A.P.J. (2004). Pooling of spare components between airlines.

Journal of Air Transport Management, vol. 10, p. 137146.

Muckstadt, J.A. (2005). Analysis and Algorithms for Service Parts Supply Chain. New York: Springer.

Ohno, T. (1988). Toyota production system: beyond large-scale production. Portland, Or: Productivity Press.

Rajarajan, S.S. (2013). Aircraft Parts Planning: Taming the Chaos. Ramco Systems Ltd.

The Free Dictionary. (2015). Turnaround Time. Retrieved November $10^{\text {th }}, 2015$. URL http://www.thefreedictionary.com/turnaround $+\mathrm{t}$ ime 